\title{
DESDE BARTHES: O FOTOBIOGRAFEMA
}

A expressão de Barthes sobre o biografema, eu a leio no seu livro sobre a fotografia, $A$ câmara clara, que talvez seja um livro sobre a morte, que talvez esclareça ao máximo o que a vida efetivamente é; assim como aquela foto tão singular, a foto da mãe de Barthes quando criança, esclarece, para ele, a essência universal da fotografia. Esclarecer seria, então, afirmar e compreender insistentemente algo, mas a partir disso que esse algo não é de modo algum. Esclarecer o ser, junto ao nada (Heidegger). A vida, junto à morte (Freud ou Bataille). O universal, junto ao singular (Barthes).

Com isso, somos conduzidos a lidar com a fotografia de maneira diametralmente oposta à de Susan Sontag, para quem, "estritamente falando, nunca se compreende nada a partir de uma foto" (2004, p. 33). Para ela, compreender é sempre negar a aparência e, portanto, a fotografia. De fato, a fotografia, tomada em toda a sua gama, é uma "desordem" que não se presta ao científico (BARTHES, 2015, p. 14). Contudo, o esclarecimento, que envolve afirmação e compreensão, não é uma operação reservada à ciência lógico-positivista. $\mathrm{O}$ esclarecimento não é o encontro de um ser anteriormente já posto, mas a abertura para um novo modo de ser, pensar e agir.

A essência da fotografia se esclarece, para Barthes, como "isso-foi". A fotografia, no seu ser, é sempre a presença de uma ausência - numa fixação. A fixação de um devir numa imagem - especula-se, a partir de uma certa documentação - surgiu do desejo de salvar o ser do nãoser, por meio do que o ser não é: a sua máscara mortuária: o seu retrato: a sua imago. Tudo passa; a fotografia sobrevive. A sobrevivência da fotografia ao seu objeto é a prova poderosa da sua onipotência. Mas a ideia da onipotência da imagem fixa determina o implante histórico da arte na magia (FREUD, 1965); mas, em nosso esclarecimento, pelo contrário, nos cabe libertar a arte da magia.

A magia se completa quando a aparência não é mais um substituto do real, mas a própria realidade. Na vigência plena do mágico, a distinção entre aparência e realidade se torna supérflua; a aparência não é mais signo, não é uma coisa que está no lugar de uma outra, não é uma referência a um referente que a transcende, mas o próprio referente, a coisa mesma. No implante da arte na magia, a aparência não é signo, mas imagem. "Ora, se o signo nos conduzia à comunicação, a imagem, em contrapartida, pode facilmente nos abrir para a arte" (SOULAGES, 2010, p. 162). A imagem não é comunicativa, isso quer dizer: ela não se inscreve no campo da consciência e do controle. A imagem é maquinação.

Desde a origem da imagem, portanto, a sua destinação é o realismo (a sua superposição perfeita à realidade) e, além disso, o realismo mágico (a indistinção total entre imagem e realidade), que André Bazin chamou de "o mito do cinema total" (2014, p. 35). De todas as imagens, porém, a fotográfica é a mais realista, porque ela se encontra numa relação ontológica irredutível e direta com o seu objeto. Segundo Bazin (2014, p. 32): "a fotografia se beneficia de uma transferência de realidade da coisa para a sua reprodução". Por isso, o advento da fotografia libertou as outras artes plásticas, como a pintura e a escultura, para o abstrato. Para Bazin, no entanto, é o cinema, e não a fotografia, que, com o acréscimo do movimento, cumpre ao máximo a destinação da imagem: salvar o ser pela aparência, tornando-se real. Mas se a origem da imagem é o desejo de vencer a morte, mediante a fixação do evanescente no eterno, Barthes discordaria do sucesso do cinema em alcançar o seu destino, pois, para ele, "no cinema,

\footnotetext{
${ }^{1}$ Universidade Federal do Tocantins (UFT), curso de Filosofia. E-mail: leon@uft.edu.br.
} 
sem dúvida, sempre há referente fotográfico, mas esse referente desliza, não reivindica em favor de sua realidade, não declara sua antiga existência" (2015, p. 77). A fotografia submetida ao fluxo cinematográfico é evanescente, não é redimida da impermanência; seu ser de imagem é ultrapassado pelo ser de outras imagens. Assim, é a fotografia - a imagem subtraída ao fluxo do ser -, e não o cinema, que cumpre ao máximo a destinação da imagem.

O retrato fotográfico, devido à sua ligação ontológica com o seu objeto, pela exposição direta do corpo à câmera analógica ou digital, sem mediação humana, é mais redentor do que qualquer outra técnica pictórica ou literária. Na produção de retratos pintados, esculpidos ou escritos, um ser humano e sua subjetividade se interpõem entre a imagem produzida e o seu objeto. Com isso, para o observador do retrato, a existência do objeto na imagem se torna duvidável, e a imagem tende a perder parte de seu efeito mágico para se substituir realmente ao objeto.

Mas a imagem fotográfica sozinha não basta para a salvação mágica do impermanente. Reconstituir a vida, salvá-la, numa imagem biográfica, a partir de fotografias: essa seria a operação do fotobiografema ${ }^{2}$. O operator dá apenas o primeiro passo na salvação, como spectrum eterno, de um corpo ou de um rosto vivo evanescente, antes de ele virar vapor absoluto. Todo retrato é parte de uma tal operação de salvamento. O operator produz a máscara mortuária, e salva um grão de vida, por meio de uma ou de muitas imagens fixas. Mas deste grão de vida é preciso revelar a vida toda, a partir da escolha das fotografias certas que podem se tornar fotobiografema.

Da fotografia ao fotobiografema: esse processo requer uma espécie de revelação, que cabe ao que toma, numa escolha, a foto em suas mãos, demoradamente. Essa revelação de uma vida, a partir de uma ou de algumas fotografias especialmente escolhidas, num fotobiografema, é uma operação atribuída ao spectator, que é, poderíamos complementar, um spectator machinosus, a quem cabe escolher aquelas fotografias que lhe toca ver, que lhe tocam, ao vêlas, a quem cabe escolher aquela ou aquelas imagens fixas pelas quais se sente atraído (numa escolha que não é livre), para, a partir delas, se relembrar, ou se reinventar, o curso de uma vida - afinal, como distinguir a memória da ficção e da maquinação, senão mediante outras fotografias e fotobiografemas? Vale notar: o verbo machinari, em latim, língua que agrada a Barthes como um "pedantismo necessário" (BARTHES, 2015, p. 68), quer dizer combinar, imaginar, tramar, urdir (GAFFIOT, 2001, p. 439).

Tomar o esclarecimento como revelação e a fixação da imagem viva como redenção de uma existência evanescente aproxima os termos da abertura e os processos fotográficos dos termos e dos processos da religião. Retratar, então, é separar um rosto, uma expressão, um corpo vivo, da sua união viva com o seu mundo histórico; retratar é sacralizar. A concepção religiosa da sacralidade da vida torna sagrado qualquer retrato, quando o retrato é escolhido por conter o grão de vida que se revela num fotobiografema.

Ora, nada nos impede de rasgar, destruir fotografias. Pois o culto do sagrado é o que o esclarecimento não é. E o esclarecimento é nossa abertura, para libertar o pensamento e a arte dos efeitos da magia. A fotografia eventualmente sobrevive ao seu objeto, ser transitório. Mas não se substitui a ele, jamais. Não, enquanto não nos enganamos. A imagem fotográfica é uma coisa em si mesma, mas é outra coisa do que seu objeto. Desejar preservar o transitório numa imagem fixa ou numa ideia fixa é a própria insanidade. A verdadeira salvação não se encontra na negação da transitoriedade dos seres que compõem o mundo, mas antes na sua afirmação. Maquinar fotobiografemas é um exercício da potência de nossa imaginação. Isto, no entanto, não é restituir à vida o que está morto; é desdobrar as direções possíveis para um grão de vida apenas virtual.

\footnotetext{
${ }^{2}$ Esta reflexão se baseia num livro inédito, sobre a ideia-gesto do "autofotobiografema", editado por François Soulages, a ser lançado em breve (2016 ou 2017) pela L'Harmattan.
} 


\section{Referências}

BARTHES, Roland. A câmara clara. Trad. Júlio Castañon Guimarães. Rio de Janeiro: Nova Fronteira, 2015.

BAZIN, André. O que é o cinema? Trad. Eloisa Araújo Ribeiro. São Paulo: Cosac Naify, 2014.

FREUD, Sigmund. Totem et tabou. Trad. Serge Jankélévitch. Paris: Payot, 1965.

GAFFIOT, Félix. Dictionnaire Latin-Français. Paris: Hachette, 1934.

SONTAG, Susan. Sobre a fotografia. Trad. Rubens Figueiredo. São Paulo: Companhia das Letras, 2004.

SOULAGES, François. Estética da fotografia. Trad. Iraci D. Poleti e Regina Salgado Campos. São Paulo: Senac São Paulo, 2010. 